\title{
Campylobacter canadensis sp. nov., from captive whooping cranes in Canada
}

\author{
G. Douglas Inglis, ${ }^{1}$ Bryanne M. Hoar, ${ }^{2}$ Douglas P. Whiteside ${ }^{2,3,4}$ \\ and Douglas W. Morck ${ }^{2,3}$
} Correspondence
G. Douglas Inglis
inglisd@agr.gc.ca

\author{
${ }^{1}$ Food Safety and Quality National Program, Agriculture and Agri-Food Canada Research Centre, \\ 5403 1st Avenue S, Lethbridge, AB, T1J 4B1, Canada \\ ${ }^{2}$ Department of Biological Sciences, Faculty of Science, University of Calgary, 2500 University \\ Drive NW, Calgary, AB, T2N 1N4, Canada \\ ${ }^{3}$ Faculty of Veterinary Medicine, University of Calgary, 2500 University Drive NW, Calgary, AB, \\ T2N 1N4, Canada \\ ${ }^{4}$ Calgary Zoo Animal Health Centre, 1625 Centre Avenue E, Calgary, AB, T2E 8K2, Canada
}

Ten isolates of a Campylobacter-like bacterium were recovered from captive whooping cranes (Grus americana), a bird whose populations have been so decimated by human activities that the species is currently classified as endangered in both Canada and the USA. In this paper, we describe the cultural and biochemical characteristics of this

Abbreviation: AFLP, amplified fragment length polymorphism.

The GenBank/EMBL/DDBJ accession numbers for the $23 \mathrm{~S}$ rRNA, $16 \mathrm{~S}$ rRNA, $r p o B$ and $c p n 60$ gene sequences of the novel isolates determined in this study are EF621904 and EF621905 (23S rRNA), EF621894EF621903 (16S rRNA), EF621885-EF621893 (rpoB) and EF621906-EF621915 (cpn60), as detailed in Figs 2-5; the accession numbers for strain L266 $^{\top}$ are respectively EF621904, EF621894, EF621885 and EF621906. bacterium and the results of a polyphasic taxonomic investigation.

Three unidentified isolates of a Campylobacter-like bacterium were recovered from cloacae of three whooping cranes in 2004 during a study to characterize the normal enteric bacterial flora of captive whooping and sandhill cranes at the Calgary Zoo (Hoar et al., 2007). Seven additional isolates were recovered from whooping cranes in 2006. Isolations were made on a Campylobacter-selective Preston medium containing selective supplement SR117 (Oxoid), Karmali agar containing selective supplement SR167 (Oxoid) or Campylobacter charcoal-deoxycholate medium (CCDA) containing selective supplement SR155 (Oxoid) incubated anaerobically $\left(10 \% \mathrm{CO}_{2}, 10 \% \mathrm{H}_{2}\right.$ and $\left.80 \% \mathrm{~N}_{2}\right)$ or microaerobically $\left(5 \% \mathrm{O}_{2}, 10 \% \mathrm{CO}_{2}, 3 \% \mathrm{H}_{2}\right.$ 
and $83 \% \mathrm{~N}_{2}$ ) at 37 or $42{ }^{\circ} \mathrm{C}$. Cultures were examined after 2,3 and 7 days incubation. The physiological characters of all ten isolates along with selected reference strains were determined using standard methods (e.g. On et al., 1996 and references therein); all tests were conducted at least two times. Morphological characteristics of the bacterium were determined using light and transmission electron microscopy (TEM). For TEM, cells ( $48 \mathrm{~h}$ old) were fixed in $2 \%$ glutaraldehyde, stained with uranyl acetate and examined with a Hitachi H-7100 microscope operated at $30 \mathrm{kV}$.

Genomic DNA was extracted using the Qiagen DNeasy tissue kit. Extracted genomic DNA was subjected to genus Campylobacter- and Campylobacter species-specific PCR (Inglis \& Kalischuk, 2003; Lawson et al., 2001). The 23S rRNA genes of two isolates, $\mathrm{L}_{266^{\mathrm{T}}}$ and L268, were amplified using the basic primers and PCR conditions published by Sallen et al. (1996) with slight modifications to the primer sequences (Inglis et al., 2006). The 16S rRNA gene was amplified using the eubacterial primers UNI27F and UNI1492R (Lane, 1991), and sequences were obtained using the primers UNI27F, UNI338F, UNI1100R and UNI1492R. The rpoB and cpn60 genes (synonyms groEL and $h s p 60$ ) were sequenced as described by Korczak et al. (2006) and Inglis et al. (2006), respectively. All sequences were compared directly with the NCBI non-redundant nucleotide database using BLASTN. Subsequently, the nucleotide sequences for the unidentified isolates were aligned along with data retrieved from NCBI using the multialignment program CLUSTAL $\mathrm{W}$, and the alignments were refined visually using GeneDoc (Nicholas \& Nicholas, 1997). Sequence data were analysed using programs contained within the phylogenetic software PHYLIP (Felsenstein, 2005). Phylogenetic estimates were obtained based on the neighbour-joining distance method. Divergence (or distance) of each pair of sequences was calculated by DNADIST using Kimura's two-parameter model. The NEIGHBOR program was used to carry out the neighbour-joining method for estimating phylogenies from the distance matrices. Support for internal branches within the resulting trees was obtained by bootstrap analysis (1000 replicates) generated by SEQBOOT, and a majority-rule consensus tree was constructed using the CONSENSE program. TreeView (Page, 2001) was used to generate rooted phylogenetic trees. Species-specific primers targeting the cpn60 gene were developed using the COnsensusDEgenerate Hybrid Oligonucleotide Primers (CODEHOP) program (http://bioinformatics.weizmann.ac.il/blocks/ codehop.html). The primers developed were CraneF (5'GAAAAAGTAGGCAAAGATGGTGTTA-3') and CraneR (5'-CAATTATTAAAAGCGGTC-3'). The predicted annealing temperature was $46.5{ }^{\circ} \mathrm{C}$, no hairpin loops or primer dimers were predicted and the projected amplicon was 253 bases long. Each primer was subjected to BLAST analysis using the NCBI website (short but nearly exact matches). The forward primer produced identical alignments to the cpn60 genes of Campylobacter jejuni,
Campylobacter coli, Helicobacter pullorum, Helicobacter pametensis and Wolinella succinogenes. In contrast, the reverse primer was predicted to be specific for the crane isolates. The PCR mixture $(20 \mu \mathrm{l})$ consisted of $2 \mu \mathrm{l} 10 \times$ buffer, $0.4 \mu \mathrm{l} 10 \mathrm{mM}$ dNTPs, $0.4 \mu \mathrm{l} 25 \mathrm{mM} \mathrm{MgCl}_{2}, 1.0 \mu \mathrm{l}$ each of $10 \mu \mathrm{M}$ solutions of CraneF and CraneR, $2.0 \mu \mathrm{l}$ BSA, $0.1 \mu \mathrm{l}$ Qiagen HotStar Taq polymerase $\left(5 \mathrm{U}^{-1}\right)$, $11.1 \mu \mathrm{l}$ Optima water and $2 \mu \mathrm{l}$ DNA (20-100 ng). PCR conditions applied were $15 \mathrm{~min}$ at $95{ }^{\circ} \mathrm{C}$ followed by 35 cycles of $30 \mathrm{~s}$ at $94{ }^{\circ} \mathrm{C}, 60 \mathrm{~s}$ at $47^{\circ} \mathrm{C}$ and $60 \mathrm{~s}$ at $72{ }^{\circ} \mathrm{C}$, followed by $10 \mathrm{~min}$ at $72{ }^{\circ} \mathrm{C}$. For DNA-DNA hybridization, the method of Mehlen et al. (2004) was employed with DNA from L266 ${ }^{\mathrm{T}}$ and L284 used as the digoxigeninlabelled probes. The $\mathrm{G}+\mathrm{C}$ content of reference strains was determined from Vandamme et al. (1991) and Logan et al. (2000). The clonality of the isolates was investigated by fluorescent amplified fragment length polymorphism (AFLP) analysis using the basic procedure described by
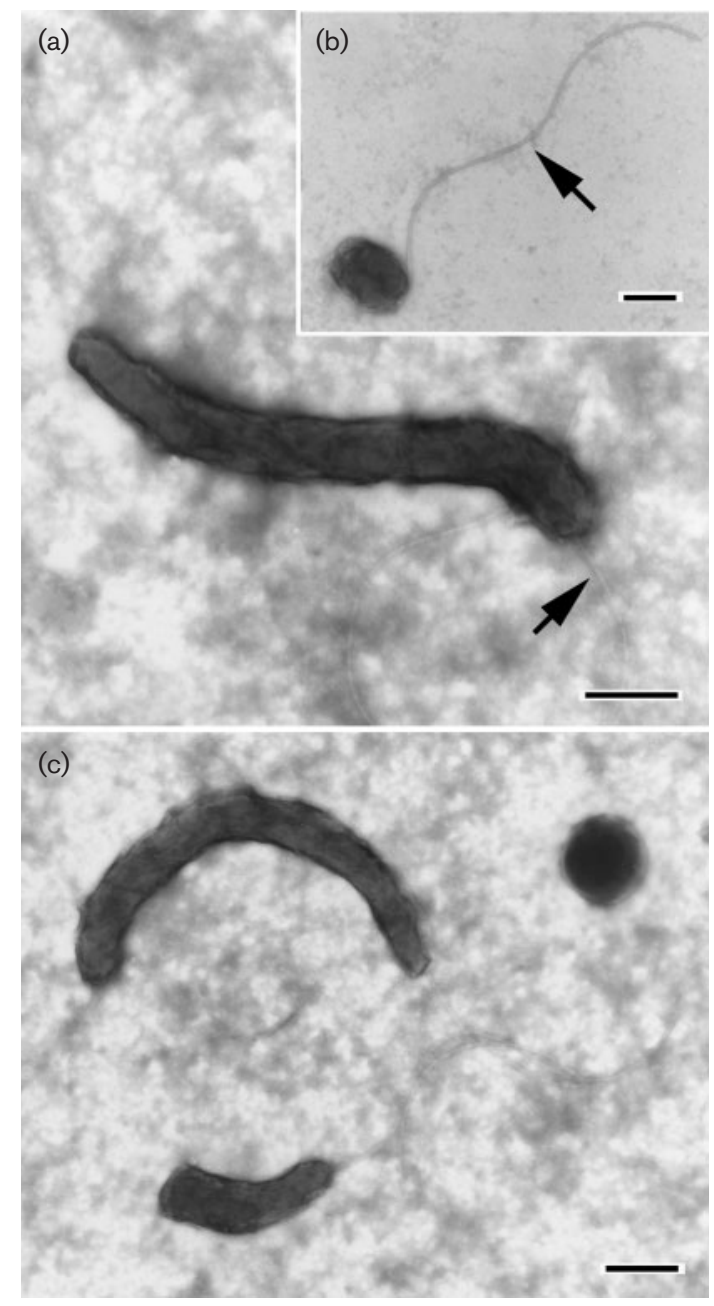

Fig. 1. Transmission electron micrographs of strain $\mathrm{L} 267$ (Campylobacter canadensis sp. nov.) showing the sigmoid form (a), coccoid form (b) and polymorphic cells (c). Bars, $500 \mathrm{~nm}$. Note the presence of a single polar flagellum (arrows). 
Table 1. Physiological characteristics of Campylobacter and Arcobacter species

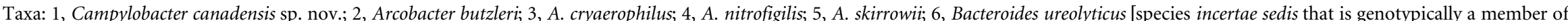

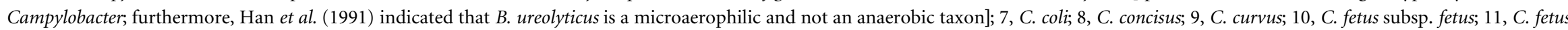

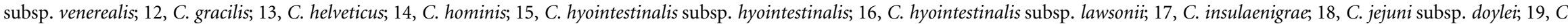

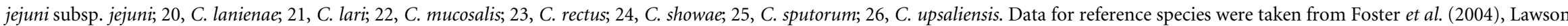

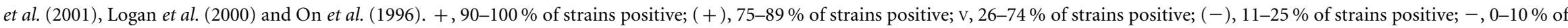
strains positive. NA, No data available.

\begin{tabular}{|c|c|c|c|c|c|c|c|c|c|c|c|c|c|c|c|c|c|c|c|c|c|c|c|c|c|c|}
\hline Characteristic & 1 & 2 & 3 & 4 & 5 & 6 & 7 & 8 & 9 & 10 & 11 & 12 & 13 & 14 & 15 & 16 & 17 & 18 & 19 & 20 & 21 & 22 & 23 & 24 & 25 & 26 \\
\hline$\alpha$-Haemolysis & - & - & - & - & + & $\mathrm{V}$ & $(-)$ & $(-)$ & $(-)$ & - & $\mathrm{V}$ & - & + & - & $\mathrm{V}$ & $\mathrm{V}$ & $\mathrm{NA}$ & + & + & - & $\mathrm{V}$ & - & + & + & + & + \\
\hline Oxidase & + & + & + & + & + & + & + & $\mathrm{V}$ & + & + & + & - & + & + & + & + & + & + & + & + & + & + & + & $\mathrm{V}$ & + & + \\
\hline Catalase & V & $\mathrm{V}$ & + & + & + & $(-)$ & + & - & - & + & $(+)$ & $\mathrm{V}$ & - & - & + & + & + & $\mathrm{V}$ & + & + & + & - & $(-)$ & + & V & - \\
\hline Hippurate hydrolysis & - & - & - & - & - & - & - & - & $(-)$ & - & - & - & - & - & - & - & - & + & + & - & - & - & - & - & - & - \\
\hline Urease production & $\mathrm{V}$ & - & - & + & - & + & - & - & - & - & - & - & - & - & - & - & - & - & - & - & $\mathrm{V}$ & - & - & - & - & - \\
\hline Nitrate reduction & $\mathrm{V}$ & + & + & + & + & + & + & $(-)$ & + & + & + & $(+)$ & + & $\mathrm{V}$ & + & + & + & - & + & + & + & - & + & + & + & + \\
\hline Alkaline phosphatase & - & - & - & - & - & - & - & $\mathrm{v}$ & $\mathrm{V}$ & - & - & - & - & - & - & $(-)$ & NA & - & - & + & - & $(+)$ & - & - & - & - \\
\hline \multicolumn{27}{|l|}{ Production on TSI agar of: } \\
\hline $\mathrm{H}_{2} \mathrm{~S}$ & $\mathrm{~V}$ & - & - & - & - & - & $\mathrm{V}$ & - & $(-)$ & - & - & - & - & - & + & + & - & - & - & - & - & + & - & $\mathrm{V}$ & + & - \\
\hline Acid and $\mathrm{H}_{2} \mathrm{~S}$ & $(-)$ & - & - & - & - & - & - & - & - & - & - & - & - & NA & - & - & NA & - & - & $\mathrm{V}$ & - & - & - & - & - & - \\
\hline Indoxyl acetate hydrolysis & - & + & + & + & + & - & + & - & $\mathrm{V}$ & - & - & $\mathrm{V}$ & + & - & - & - & - & + & + & - & - & - & + & $\mathrm{V}$ & - & + \\
\hline \multicolumn{27}{|l|}{ Growth at/in/on: } \\
\hline $25{ }^{\circ} \mathrm{C}$ (microaerobic) & - & + & + & + & + & - & - & - & - & + & + & - & - & - & $(-)$ & - & - & - & - & - & - & - & - & - & - & - \\
\hline $30^{\circ} \mathrm{C}$ (microaerobic) & - & + & + & + & + & + & + & $(+)$ & + & + & + & $\mathrm{V}$ & $\mathrm{V}$ & - & + & + & $\mathrm{NA}$ & + & + & NA & + & + & $\mathrm{V}$ & + & $(+)$ & + \\
\hline $37^{\circ} \mathrm{C}$ (microaerobic) & + & + & $\mathrm{V}$ & - & + & - & + & + & V & + & + & - & + & - & + & + & NA & + & + & + & + & + & - & $\mathrm{V}$ & + & + \\
\hline $42{ }^{\circ} \mathrm{C}$ (microaerobic) & + & $(-)$ & - & - & $(-)$ & $\mathrm{V}$ & + & $(+)$ & V & $(+)$ & - & $\mathrm{V}$ & + & $\mathrm{NA}$ & + & + & - & - & + & + & + & + & $(-)$ & $\mathrm{V}$ & + & $(+)$ \\
\hline $37^{\circ} \mathrm{C}$ (anaerobic) & + & + & $(-)$ & + & + & + & - & + & + & $(-)$ & $\mathrm{V}$ & + & - & + & - & + & - & - & - & + & - & + & + & + & + & - \\
\hline Ambient $\mathrm{O}_{2}$ & - & + & + & + & + & - & - & - & - & - & - & - & - & - & - & - & - & - & - & - & - & - & - & - & - & - \\
\hline Nutrient agar & - & + & + & + & + & + & + & $(-)$ & + & + & + & + & $(+)$ & NA & + & + & NA & + & + & NA & + & + & $(-)$ & $\mathrm{v}$ & + & + \\
\hline CCDA & + & + & + & - & + & $\mathrm{V}$ & + & $(-)$ & $(+)$ & + & + & $\mathrm{V}$ & + & $\mathrm{NA}$ & + & + & NA & + & + & NA & + & + & - & + & $(+)$ & + \\
\hline MacConkey agar & + & $(+)$ & $(-)$ & - & - & $(-)$ & $\mathrm{V}$ & - & $(+)$ & $(+)$ & $\mathrm{V}$ & $(+)$ & - & - & $\mathrm{V}$ & $\mathrm{V}$ & NA & - & - & + & - & $(+)$ & - & + & $\mathrm{V}$ & - \\
\hline $1 \%$ glycine & $\mathrm{V}$ & - & - & - & - & + & + & $(-)$ & + & + & - & + & $\mathrm{V}$ & + & + & $\mathrm{V}$ & + & $(-)$ & + & - & + & $\mathrm{V}$ & + & $\mathrm{V}$ & + & + \\
\hline $3.5 \% \mathrm{NaCl}$ & - & $\mathrm{v}$ & - & + & + & + & - & - & - & - & - & - & - & + & - & - & - & - & - & - & - & - & - & - & $\mathrm{V}$ & - \\
\hline Resistance to nalidixic acid & $\mathrm{V}$ & $(-)$ & - & - & - & - & - & $(+)$ & + & + & $\mathrm{V}$ & $\mathrm{V}$ & - & $\mathrm{V}$ & + & + & + & - & - & + & $\mathrm{V}$ & $(+)$ & $(+)$ & - & $(+)$ & - \\
\hline Resistance to cephalotin & - & + & + & - & + & - & + & - & - & - & - & - & - & - & $(-)$ & - & + & - & + & + & + & - & - & - & - & $(-)$ \\
\hline Requirement for $\mathrm{H}_{2}$ & - & NA & NA & NA & NA & NA & - & + & + & - & - & NA & - & NA & $\mathrm{v}$ & $\mathrm{V}$ & NA & - & - & - & - & + & + & + & + & - \\
\hline$\gamma$-Glutamyl transpeptidase & $(+)$ & NA & NA & NA & NA & NA & - & - & NA & - & NA & NA & - & NA & - & - & NA & NA & - & - & - & NA & NA & NA & - & - \\
\hline Nitrite reduction & + & NA & NA & NA & $\mathrm{NA}$ & NA & - & - & $\mathrm{NA}$ & - & $\mathrm{NA}$ & $\mathrm{NA}$ & - & NA & - & - & - & NA & - & $\mathrm{V}$ & - & NA & NA & NA & - & - \\
\hline Flagella & + & + & + & + & + & NA & + & + & + & + & + & - & + & - & + & + & $\mathrm{NA}$ & + & + & + & + & + & + & + & + & + \\
\hline
\end{tabular}




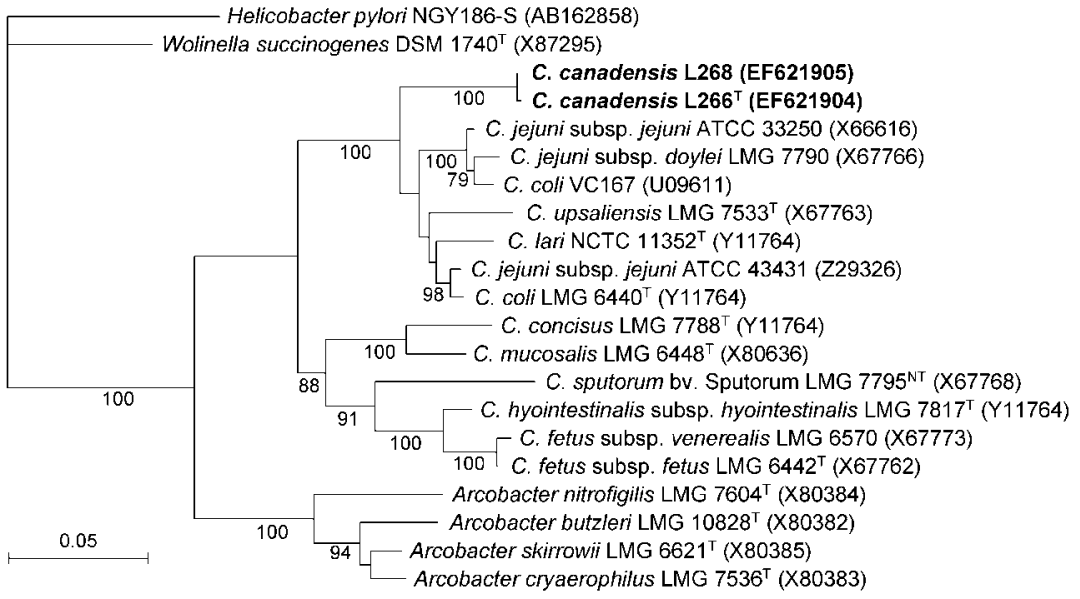

Fig. 2. Rooted tree based on $23 S$ rRNA gene sequences, showing the phylogenetic relationships of two strains of $C$. canadensis sp. nov. $\mathrm{NCBI}$ accession numbers are presented in parentheses. Bar, 0.05 nucleotide substitutions per base. Numbers at nodes $(\geqslant 70 \%)$ indicate support for the internal branches within the tree obtained by bootstrap analysis (percentages of 1000 bootstraps).

Kokotovic \& On (1999). Amplified DNA products were separated using POP7 polymer with an ABI 3130 Automated Genetic Analyzer (Applied Biosystems). Only AFLP profiles comprising fragments detected in the size range 80 to $500 \mathrm{bp}$ were considered for numerical analysis.
GENESCAN-processed data files comprising both bacterial AFLP profiles and the internal molecular mass standard (GENESCAN-500 LIZ) were imported into the program BioNumerics 4.01 (Applied Maths). After registration of strain details, profiles were normalized within and

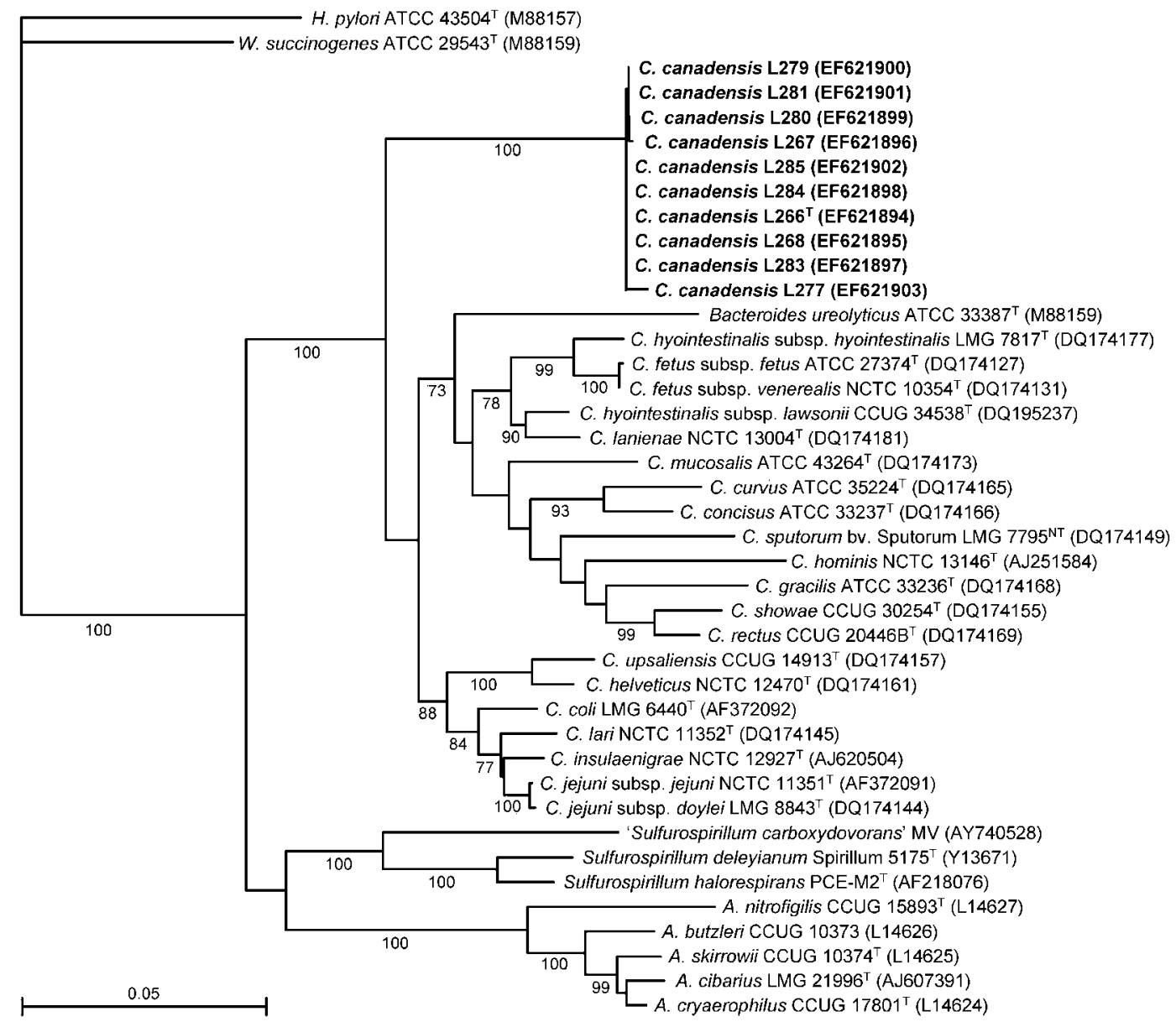

Fig. 3. Rooted tree based on $16 \mathrm{~S}$ rRNA gene sequences, showing the phylogenetic relationships of ten strains of $C$. canadensis sp. nov. Refer to Fig. 2 for further details. 


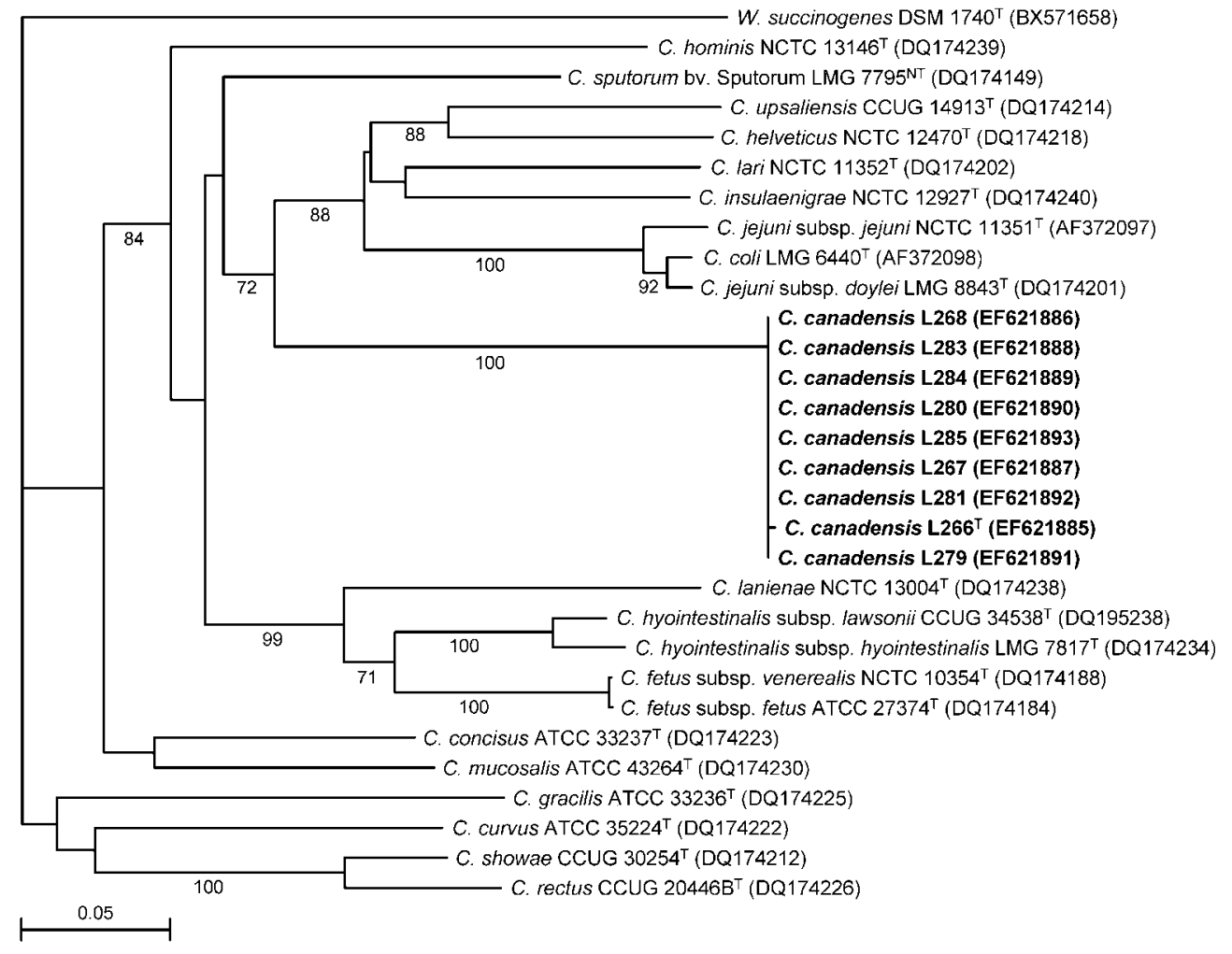

Fig. 4. Rooted tree based on $r p o B$ gene sequences, showing the phylogenetic relationships of nine strains of $C$. canadensis sp. nov. Refer to Fig. 2 for further details.

between runs by linking profiles for analysis to their respective molecular mass standard, as described in the software manufacturer's instructions. Normalized AFLP profiles were compared using the Dice coefficient and clustered by the unweighted pair group with mathematical averages (UPGMA) method.

Ten isolates of small, motile, Gram-negative bacilli were isolated from cloacal swabs of captive whooping cranes. All isolates were presumptively identified as Campylobacter based on genus-specific PCR, but were not identifiable by Campylobacter species-specific PCR. TEM revealed that cells were uniflagellate and pleomorphic, typically sigmoid to allantoid in shape but also spheroid to coccoid (Fig. 1). Sigmoid cells were $2.61 \pm 1.72 \mu \mathrm{m}$ (mean \pm SD) in length and $0.48 \pm 0.09 \mu \mathrm{m}$ in width. Spheroid cells were $0.73 \pm$ $0.16 \mu \mathrm{m}$ in length and $0.59 \pm 0.09 \mu \mathrm{m}$ in width. The following percentages of positive results for physiological characters were observed $(n=10): 0 \% \alpha$-haemolysis, $100 \%$ oxidase, $40 \%$ catalase, $0 \%$ hippurate hydrolysis, $50 \%$ urease, $50 \%$ nitrate reduction, $0 \%$ alkaline phosphatase, $40 \%$ trace $\mathrm{H}_{2} \mathrm{~S}$ production, $20 \%$ acid production on triple-sugar iron (TSI) agar, $0 \%$ indoxyl acetate hydrolysis, $0 \%$ growth at $25{ }^{\circ} \mathrm{C}$ (microaerobic), $100 \%$ growth at $37{ }^{\circ} \mathrm{C}$ (microaerobic), $100 \%$ growth at $42{ }^{\circ} \mathrm{C}$ (microaerobic), $100 \%$ anaerobic growth at $37{ }^{\circ} \mathrm{C}, 0 \%$ growth in ambient $\mathrm{O}_{2}$ at 25 or $37{ }^{\circ} \mathrm{C}, 0 \%$ growth on nutrient agar,
$100 \%$ growth on CCDA, $100 \%$ growth on MacConkey agar, $30 \%$ growth on $1 \%$ glycine, $10 \%$ growth on $3.5 \%$ $\mathrm{NaCl}, 40 \%$ resistance to nalidixic acid, $0 \%$ resistance to cephalotin, $0 \%$ required $\mathrm{H}_{2}$ within the microaerobic atmosphere, $80 \% \gamma$-glutamyl transpeptidase and $100 \%$ nitrite reduction (Table 1). The bacterium exhibited no or very restricted growth at $30{ }^{\circ} \mathrm{C}$ (microaerobically). The most useful characters that distinguished the bacterium from Arcobacter species and recognized Campylobacter taxa were negative hippurate and indoxyl acetate hydrolysis, production of $\gamma$-glutamyl transpeptidase, positive nitrite reduction, inability to grow in ambient $0_{2}$, no growth microaerobically at 25 and $30{ }^{\circ} \mathrm{C}$, inability to grow on nutrient agar and on $3.5 \% \mathrm{NaCl}$, ability to grow anaerobically and on MacConkey agar and sensitivity to cephalotin.

To determine their taxonomic position, the 23S rRNA genes of two isolates (L266 ${ }^{\mathrm{T}}$ and L268) were sequenced (approx. $2700 \mathrm{nt}$ ). A search of the NCBI database determined that the isolates were most closely related to taxa within the genus Campylobacter. Further analysis indicated that the isolates formed a robust clade $(100 \%$ bootstrap support) with other Campylobacter species, and were distinct from arcobacters (Fig. 2). Phylogenetic relationships were examined further using the 16S rRNA gene (approx. $1400 \mathrm{nt}$ ). A search of the NCBI database confirmed that the unidentified isolates were phylogeneti- 


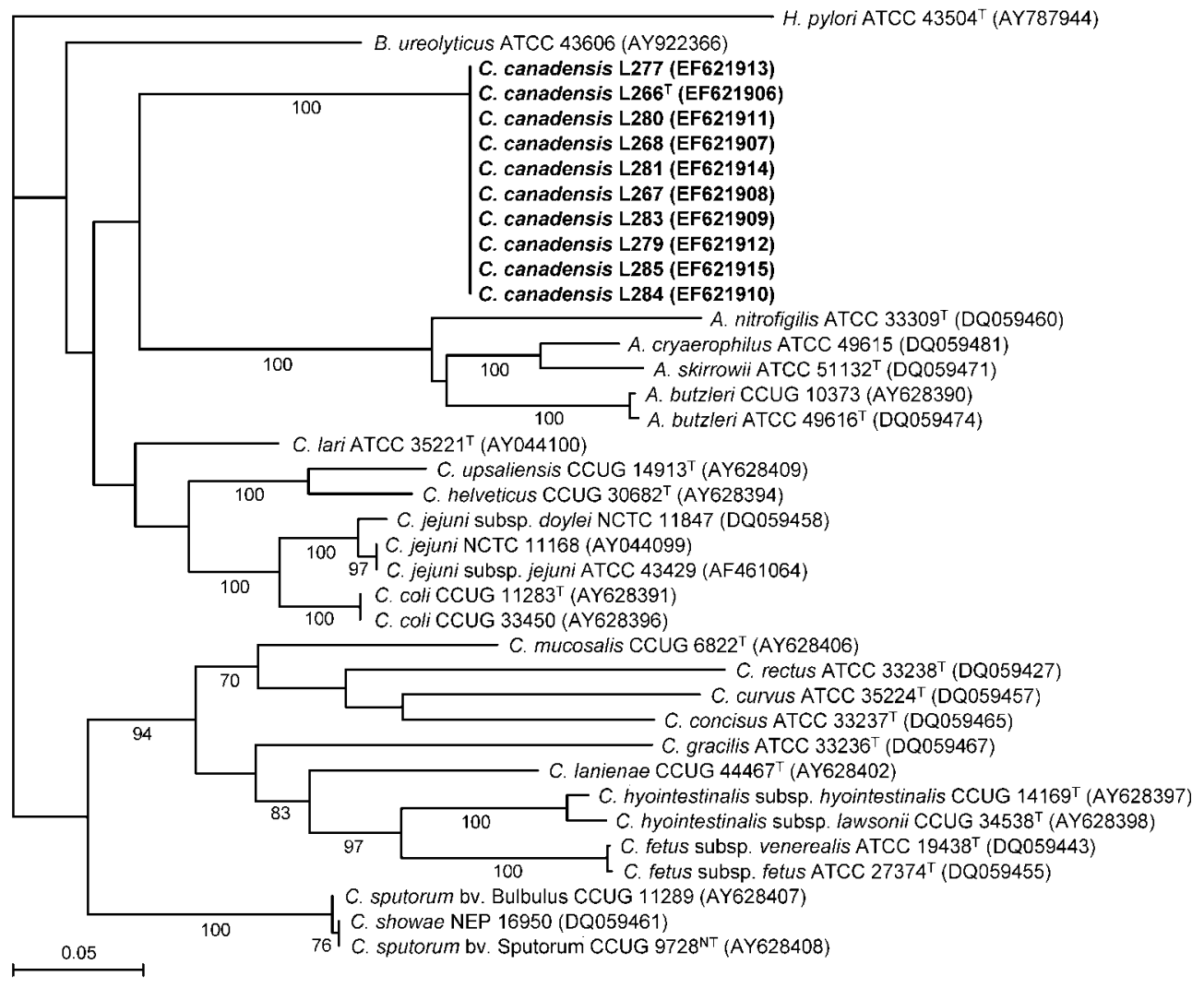

Fig. 5. Rooted tree based on cpn60 gene sequences, showing the phylogenetic relationships of ten strains of $C$. canadensis sp. nov. Refer to Fig. 2 for further details.

Table 2. DNA relatedness of strains of C. canadensis sp. nov. and other members of the genus Campylobacter

A $\Delta T_{\mathrm{m}}$ greater than $5{ }^{\circ} \mathrm{C}$ between the homologous and heterologous hybrids indicates two different species (Mehlen et al., 2004). -, No detectable DNA-DNA hybridization.

\begin{tabular}{|c|c|c|}
\hline \multirow[t]{2}{*}{ Strain } & \multicolumn{2}{|c|}{$\Delta T_{\mathrm{m}}\left({ }^{\circ} \mathrm{C}\right)$} \\
\hline & $\mathrm{L}^{266^{\mathrm{T}}}$ & L284 \\
\hline C. canadensis sp. nov. $\mathrm{L}^{2} 26^{\mathrm{T}}$ & 0.0 & 0.0 \\
\hline C. canadensis sp. nov. L284 & 0.0 & 0.0 \\
\hline C. coli $\mathrm{L} 7$ & 17.0 & - \\
\hline C. concisus ATCC $33237^{\mathrm{T}}$ & 5.2 & - \\
\hline C. fetus subsp. fetus ATCC 25936 & - & - \\
\hline $\begin{array}{l}\text { C. hyointestinalis subsp. hyointestinalis } \\
\text { CCUG } 14169^{\mathrm{T}}\end{array}$ & - & 18.7 \\
\hline C. jejuni ATCC 49943 & - & 35.7 \\
\hline C. lanienae CCUG $44467^{\mathrm{T}}$ & 11.2 & 29.1 \\
\hline C. lari $\mathrm{NCTC} 11352^{\mathrm{T}}$ & - & - \\
\hline C. sputorum bv. Sputorum CCUG $9728^{\mathrm{T}}$ & - & - \\
\hline C. upsaliensis CCUG $14913^{\mathrm{T}}$ & - & - \\
\hline
\end{tabular}

cally most closely related to Campylobacter, and pairwise sequence comparisons of $\mathrm{L}_{2} 66^{\mathrm{T}}$ with the type strains of most closely related species revealed similarities of $92 \%$ with C. jejuni and C. coli and $91 \%$ with Campylobacter lari, C. insulaenigrae, C. helveticus and C. upsalienesis. The dissimilarity in sequence with its nearest phylogenetic neighbours was substantially greater than the $3 \%$ divergence typically used to delineate different species based on $16 \mathrm{~S}$ rRNA gene sequence (Stackebrandt \& Ludwig, 1988). The neighbour-joining dendrogram indicated that all ten isolates from whooping cranes formed a robust clade (100\% bootstrap support) which was clearly distinct from Arcobacter and Sulfurospirillum strains and grouped with Campylobacter species (Fig. 3). However, the clade was very distinct from clades containing other Campylobacter species.

In view of the low $16 \mathrm{~S}$ rRNA gene sequence similarity between the unidentified isolates and other Campylobacter species, the rpoB (approx. $525 \mathrm{nt}$ ) and cpn60 (approx. $450 \mathrm{nt}$ ) genes were sequenced and genomic DNA-DNA hybridization was conducted. The $c p n 60$ and $r p o B$ genes have recently been applied to study phylogenetic relationships within the Campylobacteraceae (Hill et al., 2006; Kärenlampi et al., 2004; Korczak et al., 2006). Searches 
of the NCBI database indicated that the isolates from whooping cranes were most similar to Campylobacter species. Pairwise comparisons of sequence similarity between $\mathrm{L} 266^{\mathrm{T}}$ and Campylobacter species were $\leqslant 81$ and $\leqslant 93 \%$, respectively, for the rpoB and $c p n 60$ genes. The unidentified isolates formed robust monophyletic groupings distinct from Campylobacter and Arcobacter species for both the $r p o B$ (Fig. 4) and $c p n 60$ (Fig. 5) genes. Similarly to Korczak et al. (2006), we observed good congruence between $r p o B$ and $16 \mathrm{~S}$ rRNA gene sequence results. In contrast, analysis of the cpn60 gene indicated that the unidentified isolates were much more closely related to Arcobacter species than was indicated by the $23 \mathrm{~S}$ rRNA, $16 \mathrm{~S}$ rRNA or $r p o B$ gene sequences. The results of DNA-DNA hybridization confirmed that the unidentified isolates are genetically distinct from other Campylobacter species (Table 2); a $\Delta T_{\mathrm{m}}$ greater than $5.0{ }^{\circ} \mathrm{C}$ indicates two different species (Mehlen et al., 2004). Species-specific primers targeting the cpn60 gene that we developed were found to be specific for the unidentified species. As predicted, an amplicon of approximately $250 \mathrm{nt}$ was observed for all ten isolates recovered from cranes but not for any reference strains of Campylobacter, Arcobacter or Helicobacter.

C. jejuni, C. coli and C. lari are commonly associated with birds (e.g. Waldenström et al., 2002) and, in addition to the genotypic uniqueness we observed, the isolates from whooping cranes also differed from these three taxa physiologically. Relative to C. lari, the crane isolates were unable to grow at $30{ }^{\circ} \mathrm{C}$, grew anaerobically and on MacConkey and nutrient agars, were sensitive to cephalotin and were able to reduce nitrite. The inability to hydrolyse hippurate and indoxyl acetate, the inability to haemolyse blood or grow at $30{ }^{\circ} \mathrm{C}$, the ability to grow anaerobically and on MacConkey and nutrient agars and to reduce nitrite, combined with sensitivity to cephalotin and the ability of some strains to degrade urea, distinguished the whooping crane isolates from C. jejuni and C. coli. Interestingly, a number of studies have reported unidentified hippurate-negative and urease-positive or urease-negative Campylobacter species from a variety of avian sources (e.g. Kaneko et al., 1999; Moore et al., 2002; Waldenström et al., 2002). In some of these studies, it is possible that the Campylobacter isolates in question were C. lari. However, in others, it is very possible that the unidentified isolates represented the novel taxon described in this study. The primers that we have developed to target the cpn60 gene should prove useful in this regard.

The results of the polyphasic taxonomic study conducted and described herein clearly indicate that the isolates recovered from captive whooping cranes at the Calgary Zoo represent a unique species of Campylobacter, for which we propose the name Campylobacter canadensis sp. nov. The epithet was chosen because it pertains to the restricted geography of breeding and nesting of the migratory population of whooping cranes in the wild, and the country in which the birds examined in the current study live. Physiological characters that serve to differentiate $C$. canadensis from Arcobacter species as well as other species within the genus Campylobacter are presented in Table 1 . These characters along with species-specific primers that we developed can be used to identify $C$. canadensis. It is pertinent to note that the ten isolates of $C$. canadensis were recovered from different individuals in 2004 and 2006. AFLP genotyping indicated that considerable genetic variability existed within the strains examined (Fig. 6). Interestingly, two isolates (L267 and L281) were determined to be identical but were isolated 2 years apart and from different individuals.

\section{Description of Campylobacter canadensis sp. nov.}

Campylobacter canadensis (ca.na.den'sis. N.L. masc. adj. canadensis pertaining to Canada).

Cells are Gram-negative, motile, polymorphic in shape (sigmoid to coccoid), $0.5-0.6 \mu \mathrm{m}$ wide and $0.7-2.6 \mu \mathrm{m}$

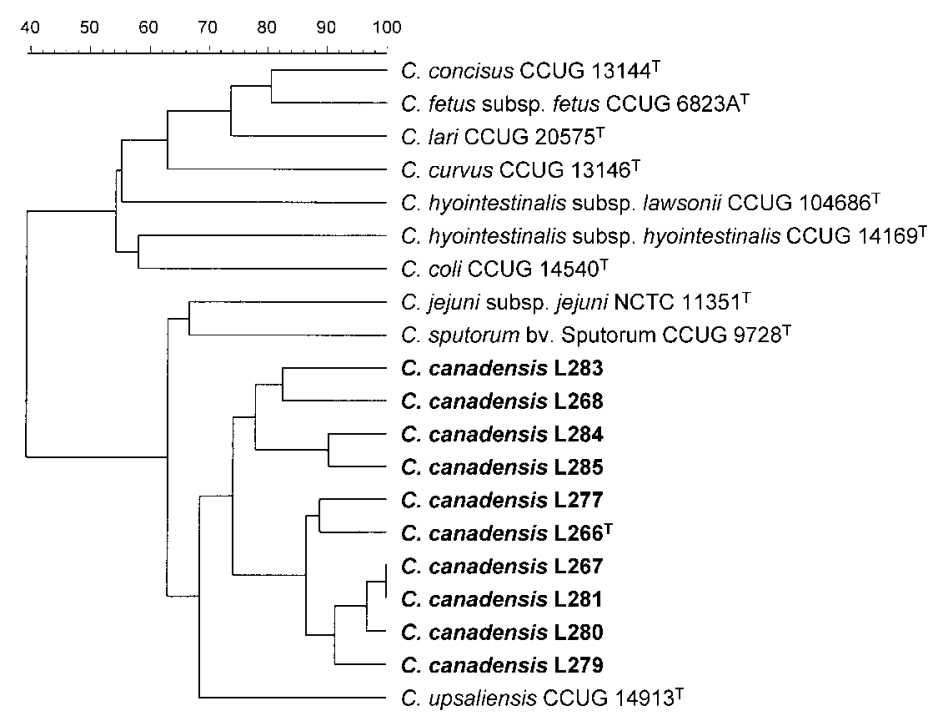

Fig. 6. Dendrogram of AFLP genotypes. 
long, possessing a single polar flagellum. On Karmali agar, colonies are whitish-grey in colour with a light centre, margins are entire and the colony surfaces are typically smooth and flat. Colonies are $0.3-2.0 \mathrm{~mm}$ in diameter at 37 and $40{ }^{\circ} \mathrm{C}$ after $48 \mathrm{~h}$. Colony appearance on CCDA, Columbia agar and trypticase soy agar is similar to that on Karmali agar, but growth on these media is slightly restricted relative to Karmali agar. Growth on MuellerHinton agar is very restricted. The bacterium is not $\alpha$-haemolytic. All strains are microaerophilic and thermophilic, able to grow well at 40 and $42{ }^{\circ} \mathrm{C}$. Under microaerobic conditions, no isolates grow at $25{ }^{\circ} \mathrm{C}$ and no or highly restricted growth occurs at $30{ }^{\circ} \mathrm{C}$; all isolates grow at 35 and $37^{\circ} \mathrm{C}$. All isolates also grow under anaerobic conditions. No detectable growth occurs under aerobic conditions at 37 or $40{ }^{\circ} \mathrm{C}$. None of the isolates hydrolyse indoxyl acetate or hippurate, produce alkaline phosphatase or require $\mathrm{H}_{2}$ to grow. All isolates produce oxidase, grow on MacConkey agar and reduce nitrite. No isolates grow on nutrient agar. Some isolates reduce nitrate $(50 \%)$, produce catalase $(40 \%)$, urease $(50 \%)$ and $\gamma$-glutamyl transpeptidase $(80 \%)$, grow on $1 \%$ glycine $(30 \%)$ and $3.5 \% \mathrm{NaCl}(10 \%)$, are resistant to nalidixic acid $(40 \%)$ and produce acid $(20 \%)$ or $\mathrm{H}_{2} \mathrm{~S}(40 \%)$ in TSI agar. All isolates are susceptible to cephalotin. No growth occurs in the presence of 2.0 or $3.5 \%(\mathrm{w} / \mathrm{v}) \mathrm{NaCl}$ at $40{ }^{\circ} \mathrm{C}$.

The type strain is $\mathrm{L}_{266^{\mathrm{T}}}\left(=\right.$ CCUG $\left.54429^{\mathrm{T}}=\mathrm{LMG} 24001^{\mathrm{T}}\right)$. This strain and other known strains were isolated from the cloacae of captive whooping cranes at the Calgary Zoo in 2004 and 2006.

\section{Acknowledgements}

The research could not have been completed without the work of a number of individuals, and we wish to thank Dwight Knapik (Calgary Zoo's Devonian Wildlife Conservation Centre) and the Calgary Zoo's veterinary staff for assisting with the sampling of the whooping crane, Linda Ward (Department of Biological Sciences, University of Calgary) for assisting with the initial isolation of $C$. canadensis, Jenny Gusse (Agriculture and Agri-Food Canada Research Centre, Lethbridge) for designing the C. canadensis-specific primers and for conducting genus- and species-specific PCR, for sequencing the $16 \mathrm{~S}$ rRNA, 23S rRNA, $r p o B$ and $c p n 60$ genes and for conducting the AFLP analysis and DNA-DNA hybridizations, Kathaleen House (Agriculture and Agri-Food Canada Research Centre, Lethbridge) for carrying out the physiological tests and Byron Lee (Agriculture and Agri-Food Canada Research Centre, Lethbridge) for conducting the transmission electron microscopy. This manuscript is contribution 387-07001 from the Agriculture and Agri-Food Canada Research Centre, Lethbridge, Alberta, Canada.

\section{References}

Felsenstein, J. (2005). PHYLIP (phylogeny inference package) version 3.6. Distributed by the author. Department of Genome Sciences, University of Washington, Seattle, USA.

Foster, G., Holmes, B., Steigerwalt, A. G., Lawson, P. A., Thorne, P., Byrer, D. E., Ross, H. M., Xerry, J., Thompson, P. M. \& Collins, M. D. (2004). Campylobacter insulaenigrae sp. nov., isolated from marine mammals. Int J Syst Evol Microbiol 54, 2369-2373.
Han, Y. H., Smibert, R. M. \& Krieg, H. R. (1991). Wolinella recta, Wolinella curva, Bacteroides ureolyticus, and Bacteroides gracilis are microaerophiles, not anaerobes. Int J Syst Bacteriol 41, 218-222.

Hill, J. E., Paccagnella, A., Law, K., Melito, P. L., Woodward, D. L., Price, L., Leung, A. H., Ng, L.-K., Hemmingsen, S. M. \& Goh, S. H. (2006). Identification of Campylobacter spp. and discrimination from Helicobacter and Arcobacter spp. by direct sequencing of PCRamplified cpn60 sequences and comparison to cpnDB, a chaperonin reference sequence database. J Med Microbiol 55, 393-399.

Hoar, B. M., Whiteside, D. P., Ward, L., Inglis, G. D. \& Morck, D. W. (2007). Evaluation of the enteric microflora of captive whooping cranes (Grus americana) and sandhill cranes (Grus canadensis). Zoo Biol 26, 141-153.

Inglis, G. D. \& Kalischuk, L. D. (2003). Use of PCR for direct detection of Campylobacter species in bovine feces. Appl Environ Microbiol 69, 3435-3447.

Inglis, G. D., McConville, M. \& de Jong, A. (2006). Atypical Helicobacter canadensis strains associated with swine. Appl Environ Microbiol 72, 4464-4471.

Kaneko, A., Matsuda, M., Miyajima, M., Moore, J. E. \& Murphy, P. G. (1999). Urease-positive thermophilic strains of Campylobacter isolated from seagulls (Larus spp.). Lett Appl Microbiol 29, 7-9.

Kärenlampi, R. I., Tolvanen, T. P. \& Hänninen, M.-L. (2004). Phylogenetic analysis and PCR-restriction fragment length polymorphism identification of Campylobacter species based on partial groEL gene sequences. J Clin Microbiol 42, 5731-5738.

Kokotovic, B. \& On, S. L. (1999). High-resolution genomic fingerprinting of Campylobacter jejuni and Campylobacter coli by analysis of amplified fragment length polymorphisms. FEMS Microbiol Lett 173, 77-84.

Korczak, B. M., Stieber, R., Emler, S., Burnens, A. P., Frey, J. \& Kuhnert, P. (2006). Genetic relatedness within the genus Campylobacter inferred from rpoB sequences. Int J Syst Evol Microbiol 56, 937-945.

Lane, D. J. (1991). 16S/23S rRNA sequencing. In Nucleic Acid Techniques in Bacterial Systematics, pp. 115-175. Edited by E. Stackebrandt \& M. Goodfellow. Chichester: Wiley.

Lawson, A. J., On, S. L. W., Logan, J. M. J. \& Stanley, J. (2001). Campylobacter hominis sp. nov., from the human gastrointestinal tract. Int J Syst Evol Microbiol 51, 651-660.

Logan, J. M. J., Burens, A., Linton, D., Lawson, A. J. \& Stanley, J. (2000). Campylobacter lanienae sp. nov., a new species isolated from workers in an abattoir. Int J Syst Evol Microbiol 50, 865-872.

Mehlen, A., Goeldner, M., Ried, S., Stindl, S., Ludwig, W. \& Schleifer, K. H. (2004). Development of a fast DNA-DNA hybridization method based on melting profiles in microplates. Syst Appl Microbiol 27, 689-695.

Moore, J. E., Gilpin, D., Crothers, E., Canney, A., Kaneko, A. \& Matsuda, M. (2002). Occurrence of Campylobacter spp. and Cryptosporidium spp. in seagulls (Larus spp.). Vector Borne Zoonotic Dis 2, 111-114.

Nicholas, K. B. \& Nicholas, H. B. (1997). GeneDoc: a tool for editing and annotating multiple sequence alignments. http://www.nrbsc.org/ gfx/genedoc/index.html

On, S. L. W., Holmes, B. \& Sackin, M. J. (1996). A probability matrix for the identification of campylobacters, helicobacters and allied taxa. J Appl Bacteriol 81, 425-432.

Page, R. D. M. (2001). TreeView. http://taxonomy.zoology.gla.ac.uk/ rod/rod.html

Sallen, B., Rajoharison, A., Desvarenne, S., Quinn, F. \& Mabilat, C. (1996). Comparative analysis of $16 \mathrm{~S}$ and $23 \mathrm{~S}$ rRNA sequences of Listeria species. Int J Syst Bacteriol 46, 669-674.

Stackebrandt, E. \& Ludwig, W. (1988). 16S ribosomal RNA cataloging. Methods Enzymol 167, 132-138. 
Vandamme, P., Falsen, E., Rossau, R., Hoste, B., Segers, P., Tytgat, R. \& De Ley, J. (1991). Revision of Campylobacter, Helicobacter, and Wolinella taxonomy: emendation of generic descriptions and proposal of Arcobacter gen. nov. Int J Syst Bacteriol 41, 88-103.
Waldenström, J., Broman, T., Carlsson, I., Hasselquist, D., Achterberg, R. P., Wagenaar, J. A. \& Olsen, B. (2002). Prevalence of Campylobacter jejuni, Campylobacter lari, and Campylobacter coli in different ecological guilds and taxa of migrating birds. Appl Environ Microbiol 68, 5911-5917. 